\title{
Anomaly of left coronary artery
}

Finesa A. Hasye ${ }^{1}$, Yerizal Karani ${ }^{2}$

1. Polri Said Sukanto Hospital, Jakarta; 2. Cardiology and Vascular Medicine, Faculty of Medicine, Universitas Andalas

Correspondence: Finesa A. Hasye, email: kardiologiunand@yahoo.com

\begin{abstract}
Anomalies of the coronary artery are uncommon, with a reported incidence of $0.3 \%$ to $1.3 \%$ in the coronary angiography studies routinely performed for suspected atherosclerotic coronary disease. There were $0.92 \%$ incidence of anomalous origination of the right coronary artery from the left sinus and the $0.15 \%$ incidence of anomalous origination of the left coronary artery from the right sinus. Most coronary artery anomalies are diagnosed by invasive angiography performed to investigate suspected atherosclerotic coronary disease. There are two important managements for patient with anomaly coronary artery. First, these coronary anomalies should result in exclusion from participation in intense competitive sports to reduce the risk of a cardiac event or sudden death. Second, and more importantly, treatment for wrong sinus coronary artery anomalies are revascularization can be either surgical or percutaneous. Surgical intervention should be considered for high-risk varieties of anomalous coronary arteries, as this is the only treatment that has been demonstrated to improve coronary blood flow and carries a low morbidity and mortality.
\end{abstract}

Keywords: anomaly coronary artery; left coronary artery anomaly; management anomaly coronary artery

\section{Abstrak}

Anomali arteri koroner jarang terjadi, dengan kasus yang dilaporkan 0,3\% hingga 1,3\% dalam penelitian angiografi koroner yang secara rutin dilakukan untuk suspek penyakit koroner aterosklerotik. Ada 0,92\% insiden anomali arteri koroner kanan dari sinus kiri dan 0,15\% insiden anomali dari arteri koroner kiri dari sinus kanan. Sebagian besar anomali arteri koroner didiagnosis dengan angiografi invasif yang dilakukan untuk menyelidiki adanya dugaan penyakit koroner aterosklerotik. Ada dua manajemen penting untuk pasien dengan arteri koroner anomali. Pertama, anomali koroner ini harus membuat penderita berhenti melakukan olahraga kompetitif untuk mengurangi risiko serangan jantung atau kematian mendadak. Kedua, dan yang lebih penting, terapi anomali arteri koroner sinus adalah revaskularisasi dapat berupa pembedahan atau percutaneous. Intervensi bedah harus dipertimbangkan untuk risiko tinggi dari arteri koroner anomali, karena ini adalah satu-satunya pengobatan yang telah ditunjukkan untuk meningkatkan aliran darah koroner dan membawa morbiditas dan mortalitas yang rendah.

Kata kunci: anomali arteri koroner; anomali arteri koroner kiri; manajemen anomali arteri koroner 


\section{INTRODUCTION}

Anomalies of the coronary artery are uncommon, with a reported incidence of $0.3 \%$ to $1.3 \%$ in the coronary angiography studies routinely performed for suspected atherosclerotic coronary disease. The forms of presentation of this condition including angina, acute myocardial infarction, heart failure, sudden death, and syncope. Particularly noteworthy were the $0.92 \%$ incidence of anomalous origination of the RCA from the left sinus and the $0.15 \%$ incidence of anomalous origination of the left coronary artery from the right sinus (for a total incidence of $1.07 \%$ for anomalous origination of a coronary artery from the opposite sinus). ${ }^{1,2}$

Anomalous origin of the left coronary artery in the right sinus of valsalva is an uncommon malformation, accounting for $0.15 \%$ of cases in the series of Angelini et al. The anomalous artery can have various courses; however, the interarterial course between the aorta and pulmonary artery is the one most frequently associated with sudden death, particularly during or immediately after strenuous physical exercise. ${ }^{1,3}$

Several hypotheses have been proposed to explain this phenomenon: expansion of the aortic and pulmonary roots during systole could cause compression of a common trunk with an anomalous course, or excessive angulation at the origin of an anomalous coronary could compromise the lumen when there is dilation of the aortic. ${ }^{1,3}$ Most coronary artery anomalies are diagnosed by invasive angiography performed to investigate suspected atherosclerotic coronary disease. Nevertheless, other diagnostic modalities, such as TEE, MRI and CT can provide more complete assessment of the course of the anomalous coronary and its anatomical relationship with neighbouring structures. ${ }^{1}$

There are two important managements for patient with anomaly coronary artery. First, these coronary anomalies should result in exclusion from participation in intense competitive sports to reduce the risk of a cardiac event or sudden death. Second, and more importantly, wrong sinus coronary artery anomalies are revascularization can be either surgical or percutaneous. ${ }^{4,5}$

This case report would like to discuss diagnosis and management of Anomaly Left Coronary artery.

\section{CASE}

A 58-years-old woman presented to the emergency room of dr. M Djamil Hospital Padang on December $5^{\text {th }}, 2016$ with chief complaint was chest pain since 2 weeks before admission. chest pain felt heavy in the middle of the chest, referred to the back, intermittently with duration less than 20 minutes, worsened by activities, relieved with rest and sublingual isosorbide dinitrate. Supporting symptoms was diaphoresis, nausea, and vomiting. Chest pain has been revealed since 2 years ago with milder intensity. She was hospitalized at Ahmad Moechtar Hospital about 1 week ago with the similar 
symptom with treatment ASA $1 \times 100 \mathrm{mg}$, clopidogrel $1 \times 75 \mathrm{mg}$, Isosorbide nitrate $3 \times 5$ $\mathrm{mg}$, bisoprolol $1 \times 2.5 \mathrm{mg}$, atorvastatin $1 \times 20$ $\mathrm{mg}$, amlodipine $1 \times 5 \mathrm{mg}$. Shortness of breath felt while chest pain occurred. There was no history of dyspnoea on effort (DOE), paroxysmal nocturnal dyspnoea (PND), orthopnoea (OP), and ankle swelling. There was no complaint of palpitation, dizziness, and syncope. Risk factor for coronary artery disease was menopause.

On physical examination, she was compos mentis cooperative, blood pressure of $177 / 85 \mathrm{mmHg}$, pulse rate of $76 \mathrm{x} / \mathrm{min}$, respiratory rate of $22 x / \mathrm{min}$. Jugular venous pressure of $5+0 \mathrm{cmH} 2 \mathrm{O}$. From cardiac examination, ictus cordis was palpable at 1 finger lateral linea mid clavicularis sinistra intercostal space V. From auscultation, the S1-S2 were normal, there were no murmur and gallop. From lung examination found vesicular without sound without rales and wheezing. Extremities were warm without ankle swollen.

The 12-lead electrocardiogram showed sinus rhythm, QRS rate 70x/i, Axis LAD, $P$ wave normal, PR interval 0.20", QRS duration 0.08 , ST-T change (-), RVH (-), LVH (-) (Figure 1).

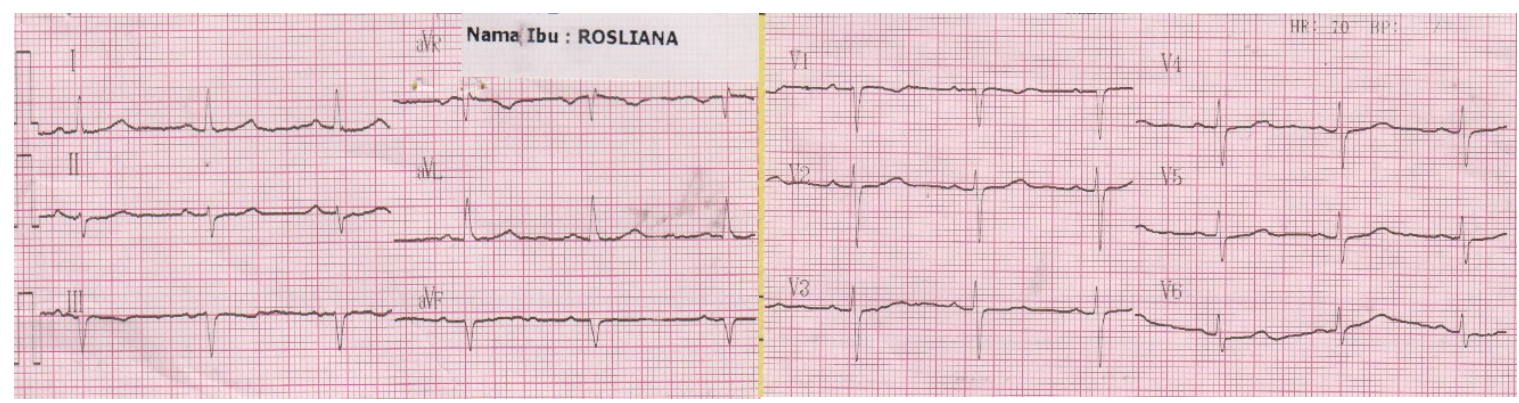

Figure 1. Electrocardiogram

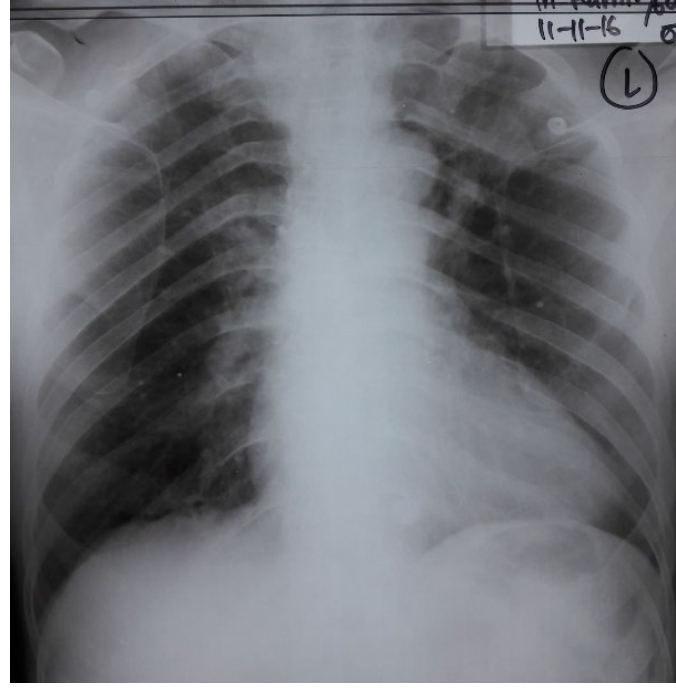

Figure 2. Chest X-Ray

The Chest X-ray showed cardio thoracic ratio (CTR) 58\%, aortic segment and pulmonal segment were normal, apex downward, without infiltrate and cranialization (Figure 2).

The laboratory findings $\mathrm{Hb}$ of $14.7 \mathrm{gr} / \mathrm{dl}$; WBC count of $9,400 / \mathrm{mm}^{3}$, haematocrit of $43 \%$, platelet of $233,000 / \mathrm{mm}^{3}$. Random Blood Glucose of $123 \mathrm{mg} / \mathrm{dl}$, urea of 11 $\mathrm{mg} / \mathrm{dl}$, creatinine of $0.8 \mathrm{mg} / \mathrm{dl}$ (Creatinine Clearance Test (CCT) 85). Sodium of 142 $\mathrm{mmol} / \mathrm{L}$, potassium of $4.5 \mathrm{mmol} / \mathrm{L}$, chloride of $109 \mathrm{mmol} / \mathrm{L}$, calcium of $9.6 \mathrm{mmol} / \mathrm{L}$. Total cholesterol of $183 \mathrm{mg} / \mathrm{dl}$, LDL of 94 $\mathrm{mg} / \mathrm{dl}, \mathrm{HDL}$ of $33 \mathrm{mg} / \mathrm{dl}$, Triglyceride of 279 $\mathrm{mg} / \mathrm{dl}$, uric acid of $6.4 \mathrm{mg} / \mathrm{dl}$.

Echocardiography (November $8^{\text {th }}, 2016$ ) showed decrease global systolic function 
EF 52\%, hypokinetic at inferior, inferolateral, and inferoseptal, normo kinetic in other segment, LV diastolic dysfunction, leaflets were normal, good RV contractility.

The working diagnosis were stable angina pectoris CCS III-IV pro-cath standby PTCA, hypertension stage I, Old myocardial infarction inferior. We treated the patient with ASA $1 \times 100 \mathrm{mg}$, ISDN $3 \times 5 \mathrm{mg}$, atorvastatin $1 \times 20 \mathrm{mg}$, bisoprolol $1 \times 2.5 \mathrm{mg}$, amlodipine $1 \times 5 \mathrm{mg}$, lansoprazole $1 \times 30 \mathrm{mg}$, laxadyn 1x10 cc, diazepam 1x5 mg.

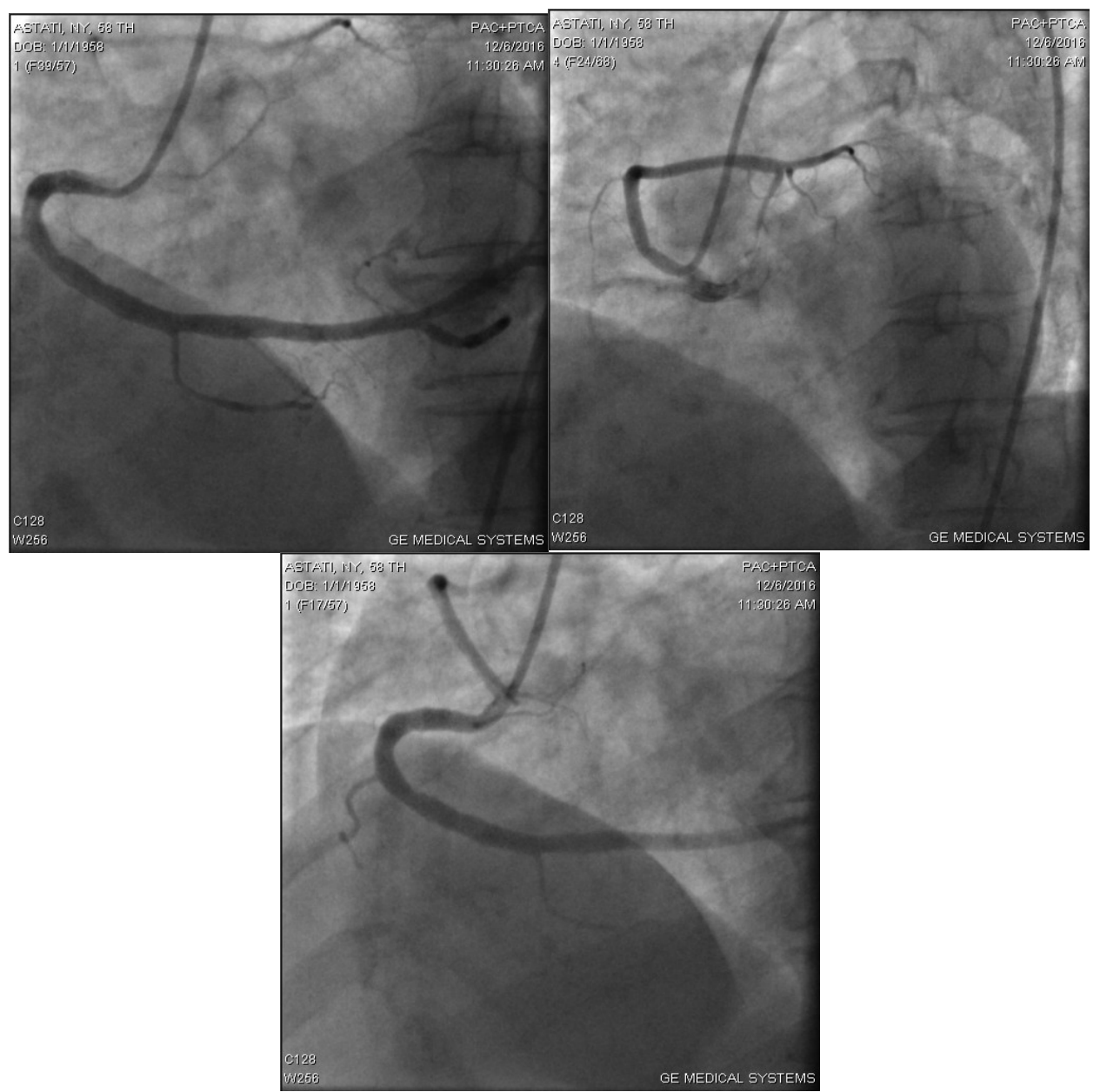

Figure 3. Angiography

On December $6^{\text {th }}, 2016$, cath standby PTCA was performed with the results irregular LAD, left coronary artery (LCA) originated from the right side. We performed echocardiography after that with the results normal global systolic function EF $56 \%$ (simpson), mild hypokinetic at basal inferior, inferoseptal, apikoseptal, normo kinetic in other segments, good LV diastolic function, normal leaflets and normal RV contractility (Figure 3).

Patient diagnosis then confirmed as anomaly left coronary artery. The advised was optimal medical therapy. Patient was discharged with therapy amlodipine 1x5 $\mathrm{mg}$, bisoprolol $1 \times 2.5 \mathrm{mg}$, atorvastatin $1 \times 20$ 
mg. We suggest the patient to do CT angiography as a gold standard.

\section{DISCUSSIONS}

A 58-years-old woman had been diagnosed as stable angina pectoris based on anamnesis, physical examination, electrocardiography, chest X-ray, echocardiography. After angiography was performed, we confirmed that she has anomaly left coronary artery.

Table 1. Classification of coronary anomalies proposed by Rigatelly ${ }^{5}$

Hypoplasia/atresia

Hyperdominance (single vessel coronary artery)

Fistulas

Originating in other arteries

Originating in the wrong sinus

Splitting (including separate origins for LAD, $\mathrm{Cx}$, and dual $\mathrm{AD}$ )

Intramyocardial tunneling

* LAD indicates anterior descending coronary artery; $\mathrm{Cx}$, circumflex coronary artery

Coronary artery anatomy including the many variations in the number and size of branches and course of the different arteries. From the right and left aortic sinuses arise the right and left coronary arteries, respectively, and their ostia, which normally originate about two-thirds the distance from the aortic annulus to the sinotubular junction and about midway between the aortic commissures. ${ }^{4}$ There is an ongoing debate to what should be considered normal and what should be considered a coronary artery anomaly (CAA). According to Angelini, CAA are diagnosed by exclusion, which means that, in those cases in which the coronary artery morphology is not normal. There are several classifications. A new one which attempts to standardize diagnostic criteria and groups CAA according to 7 categories has recently been proposed (Table 1 ). International groups are calling for registries including at least those anomalies that cause the majority of the clinical events (sudden death and myocardial ischemia) attributed to CAA, constituted by those originating in the contralateral or "wrong" sinus of Valsalva. This group includes single vessel coronary arteries ("hyper dominance" in the classification of Rigatelli et al), since they have to supply blood to the myocardium arising from a single coronary ostium and establish routes that occasionally are similar to those of the CAA with origin in the wrong sinus of Valsalva (Table 2 ). ${ }^{5}$

Table 2. Coronary artery anomalies with origin in the wrong sinus of valsava and risk of coronary ischemia and/or sudden death ${ }^{5}$

\begin{tabular}{ccc}
\hline Low risk & Intermediate risk & High risk \\
\hline Cx originating in RCA or in RCS & & \\
& LCA originating in RCS & LCA originating in RCS \\
& (interarterial course) \\
& RCA originating in LCS & RCA originating in LCS \\
& (interarterial course) \\
& LAD originating in RCS & LAD originating in RCS \\
& SVCA & (interarterial course) \\
SVCA & SVCA (interarterial course) \\
\hline
\end{tabular}


Anomalies of the coronary artery are uncommon, with a reported incidence of $0.3 \%$ to $1.3 \%$ in the coronary angiography studies routinely performed for suspected atherosclerotic coronary disease. The forms of presentation of this condition include angina, acute myocardial infarction, heart failure, sudden death, and syncope. The first clinical symptom may occur suddenly, especially during exertional activities. ${ }^{1,2}$ From anamnesis, the patient had chest pain since 2 weeks before admission. chest pain felt heavy in the middle of the chest, referred to the back, intermittently with duration less than 20 minutes, worsened by activity, relieved with rest and sublingual isosorbide dinitrate.

Anomalous origin of the left coronary artery in the right sinus of Valsalva is an uncommon malformation, accounting for $0.15 \%$ of cases in the series of Angelini et al. The anomalous artery can have various courses; however, the interarterial course between the aorta and pulmonary artery is the one most frequently associated with sudden death, particularly during or immediately after strenuous physical exercise. ${ }^{1,3}$

Several hypotheses have been proposed to explain this phenomenon. The cause is considered to be the marked angulation of the anomalous artery where it emerges from the aorta. In contrast to a normal coronary artery, which is perpendicular to the aorta at its origin, the anomalous coronary artery has to bend over itself to reach, from the opposite sinus of Valsalva, its normal supply territory. Because of this, the ostium of the anomalous coronary artery would be smaller, with valve-like ridges, as compared to the normal circular ostium, and could become compressed in the case of a marked expansion of the aorta, such as that observed during strenuous exercise. Another theory refers to the initial course of the CAA. When it is interarterial, between the aorta and pulmonary artery, the increase in the pressure in the 2 vessels, occurring during exertion, would produce a compression of the anomalous coronary artery. Moreover, if the initial pathway is intramural, the obstruction may be enhanced since the coronary artery can become deformed within the aortic wall during periods of hypertension. Some authors consider that the mechanism leading to ischemia involves the production of a spasm in the anomalous coronary artery as a result of endothelial damage produced by the anomalous pathway, and others, that an intussusception of the proximal portion of the CAA in the aortic wall would be produced. ${ }^{4}$

Physical examination and diagnostic studies may not reveal the anomaly in the absence of symptoms of infarction or ischemia. Resting electrocardiograms are usually normal. ${ }^{4}$ In this patient we found high blood pressure, but the others were in normal limit. From electrocardiogram showed normal interpretation. 
Most coronary artery anomalies are diagnosed by invasive angiography performed to investigate suspected atherosclerotic coronary disease. Nevertheless, other diagnostic modalities, such as TEE, MRI and CT can provide more complete assessment of the course of the anomalous coronary and its anatomical relationship with neighbouring structures. When the anomaly is associated with obstructive coronary lesions, the ischemic symptoms are usually attributed to these lesions; nevertheless, the anomaly, itself, can also be the cause of the symptoms, and treatment planning in these cases may be complex. ${ }^{1}$ In this patient we found anomaly left main coronary artery arise from right coronary sinus from angiography.

There are four subtypes of anomalous origin of the left main coronary artery from the right coronary sinus. It has been reported that anomalous coronary arteries are prone to atherosclerosis. The path of the first type is anterior to right ventricular outflow tract before reaching the anterior sulcus, the usual area of bifurcation. The second type courses behind the right ventricular outflow. The third one courses dorsal to the ascending aorta. These three types in absence of atherosclerotic plaque obstruction are benign. The fourth type arises from the right sinus of valsalva and passes obliquely between the aorta and pulmonary trunk. This latter type is the only one predisposing to sudden death (Figure 4). 5,9 About half of the patients with anomalous LCA arising from the right coronary sinus die before the age of 20 years, and usually during or shortly after vigorous exertion. However, our patient did not have any cardiac symptoms until the age 58 years.

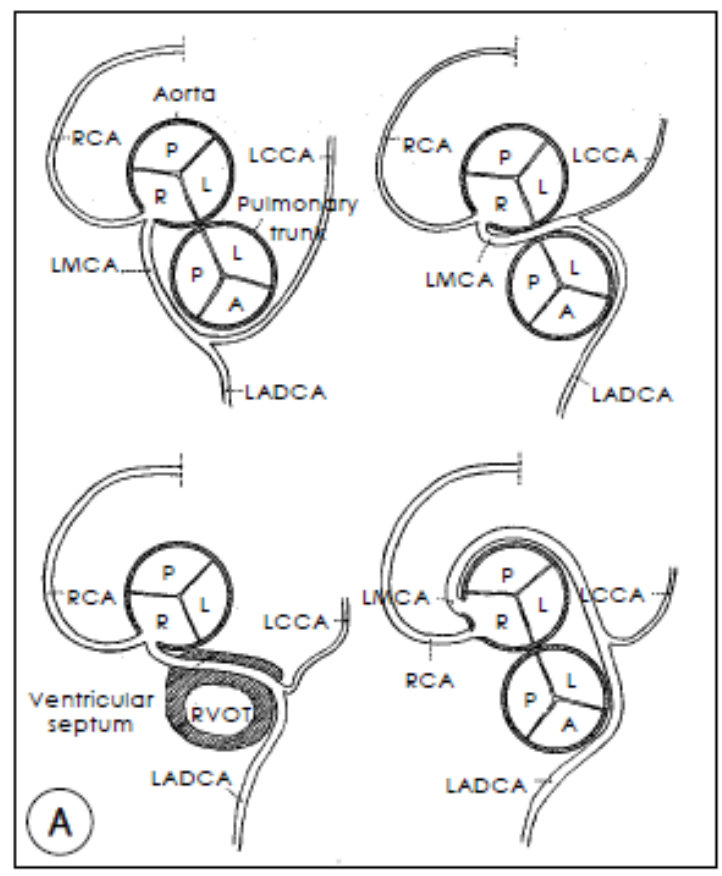

Figure 4. Anomaly left coronary artery subtype $^{6}$

Anomaly left coronary artery is considered more serious than anomaly right coronary artery because of larger amount of left ventricular myocardium at ischemic risk. ${ }^{7}$

There are two important managements for patient with anomaly coronary artery. First, these coronary anomalies should result in exclusion from participation in intense competitive sports to reduce the risk of a cardiac event or sudden death. ${ }^{5}$ For nonsurgical treatment, a small number of case reports claim successful use of betablockers in adults to treat this condition. ${ }^{9}$ Second, and more importantly, wrong sinus coronary artery anomalies are revascularization can be either surgical or percutaneous. $^{6}$ Surgical revascularization 
involves aortocoronary bypass, ostial reimplantation or the unroofing technique, which frees the intramural segment of the CAA by means of an incision in the wall shared by the CAA and the aorta, thus creating a new, larger orifice in the appropriate. There is a great deal of controversy concerning surgical revascularization in these patients, especially in young people. Aortocoronary bypass grafting has been strongly criticized, because of its "limited" patency and the inevitable competitive flow between the bypass and the CAA. Thus, the unroofing technique, which would appear to be more physiological, is increasingly being adopted. $^{5}$

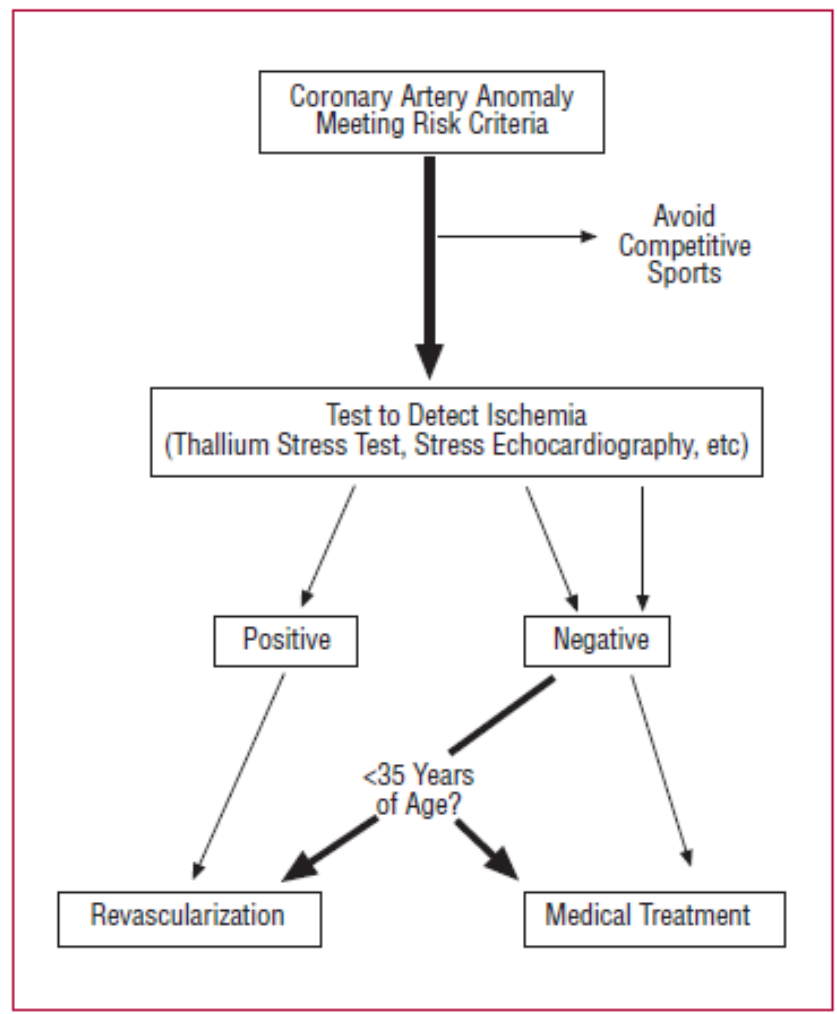

Figure 5. Therapeutic protocol proposed for coronary anomalies with origin in contralateral sinus of Valsalva in the presence of risk factors ${ }^{5}$

Percutaneous intervention, with implantation of stents in the region of the compression between the large vessels and in the anomalous ostium, has been performed in several cases, in adults, with short-term success. To date, surgical revascularization is preferred in young patients and the percutaneous procedure is performed only in adults. Evidently, in both cases, long term follow-up is necessary. ${ }^{5}$

\section{CONCLUSIONS}

There are two important managements for patient with anomaly coronary artery. First, these coronary anomalies should result in exclusion from participation in intense competitive sports to reduce the risk of a cardiac event or sudden death. Second, and more importantly, treatment for wrong sinus coronary artery anomalies 
are revascularization can be either surgical or percutaneous. Surgical intervention should be considered for high-risk varieties of anomalous coronary arteries, as this is the only treatment that has been demonstrated to improve coronary blood flow and carries a low morbidity and mortality.

\section{REFERENCES}

1. Balaguer-Malfag JR, Estornell-Erill J, Vilar-Herrero JV, Pomar-Domingo F, Federico-Zaragoza P, Payá-Serrano R. Anomalous Left Coronary Artery from the Right Sinus of Valsalva Associated With Coronary Atheromatosis. Revista Brasileira de Cardiologia Invasiva. 2005; 58(11):1351-4. doi: 10.1016/S1885-5857(06)60423-4.

2. Farias DCC, Moreira ACV, Tavares JM, Correia JNF, Souza RS, Filho ARS. Anomalous Origin of the Left Coronary Artery from the Right Sinus of Valsalva. Revista Brasileira de Cardiologia Invasiva. 2013; 21(1):82-4. doi: 10.1016/S2214-1235(15)30110-1.

3. Carvalho MS, Gonçalves Pde A, Marques H, de Sousa PJ, Calé R, Dores H, et al. Anomalous origin of left coronary artery: A malignant interarterial variant with a benign clinical course. Rev Port Cardiol. 2012; 31(6):455-8. doi: 10.1016/i.repc.2011.11.010.

4. Malouf JF, Edwards WD, Tajik AJ, Seward JB. Functional Anatomy of the Heart. New York: McGraw-Hill; 2011.

5. Barriales-Villa R, Morís de la Tassa C. Congenital Coronary Artery Anomalies With Origin in the Contralateral Sinus of Valsalva: Which Approach Should We Take?. Rev Esp Cardiol. 2006; 59(4):360-70.

6. Cho HO, Cho KH, Jeong YS, Ahn SG, Choi SJ, Yoo JY, et al. Anomalous Origin of the Left Coronary Artery from the Right Sinus of Valsalva, which Presented as Acute Myocardial Infarction. Korean Circulation J. 2006; 36:817-819.

7. Kukreti V, Norozi K, Tweedie E, Killorn E. Anomalous origin of left main coronary artery from the right sinus of Valsalva leading to sudden death. Journal of Pediatric Intensive Care. 2012; 1(2):115-120.

8. Sloan $\mathrm{K}$, Majdalany $\mathrm{D}$, Connolly $\mathrm{H}$, Schaff $\mathrm{H}$. Inferior wall myocardial infarction caused by anomalous right coronary artery. Can J Cardiol. 2008; 24(12):102-103.

9. Poormoghaddas $\mathrm{M}$, Abdi $\mathrm{A}$, Fard $\mathrm{OH}$. Anomalous origin of the left coronary artery from the right sinus of valsalva and sever mitral stenosis. ARYA Atheroscler. 2011; 6(4):149-152.

10. Angelini P. Coronary Artery Anomalies. Circulation. 2007; 115:1296-1305. doi: 10.1161/CIRCULATIONAHA.106.618082. 